\title{
Hague Case Law - Latest Developments
}

\author{
Erik V. Koppe ${ }^{1}$
}

Published online: 30 November 2015

(C) The Author(s) 2015. This article is published with open access at Springerlink.com

\section{Permanent Court of Arbitration}

\section{(1) Arctic Sunrise Arbitration (Netherlands v. Russia)}

On 14 August 2015, an Arbitral Tribunal constituted under Annex VII of the United Nations Convention on the Law of the Sea (UNCLOS) and facilitated by the Permanent Court of Arbitration (PCA) rendered its award in the dispute between the Netherlands and the Russian Federation concerning measures taken by Russia against the Arctic Sunrise and its crew. The Arctic Sunrise sailed under the flag of the Netherlands and was used by Greenpeace International to stage a protest against a Russian offshore oil platform in the Barents Sea. On 19 September 2013, the Arctic Sunrise was boarded, seized and detained by the Russian authorities, it was then towed to Murmansk and its crew were arrested.

As a follow-up to its Award on Jurisdiction of 26 November 2014, in which it decided that Russia's Declaration upon the ratification of UNCLOS did not have the effect of excluding the dispute from the jurisdiction of the Tribunal, the Tribunal held that it had jurisdiction over all claims submitted by the Netherlands and that all claims were admissible. Further, the Tribunal held, among other things, that Russia had breached its obligations towards the Netherlands as the flag State under Articles 56(2), 58(1), 58(2), 87(1)(a) and 92(1) of UNCLOS by boarding, investigating, inspecting, arresting, detaining, and seizing the Arctic Sunrise without the prior

For the full award, see: http://www.pca-cpa.org.

Erik V. Koppe

e.v.koppe@asser.nl

1 Leiden Law School, Leiden, The Netherlands 
consent of the Netherlands and by arresting, detaining, and initiating judicial proceedings against the crew of the Arctic Sunrise.

In view of the facts and circumstances of the case, the boarding, seizing, and detention of the Arctic Sunrise could not be justified on any ground, including (and in particular), the right of hot pursuit set out in Article 111 UNCLOS. Although the Russian authorities had sufficient reason to commence pursuit under Article 111 UNCLOS following the violations by the Arctic Sunrise's rigid hull inflatable boats (RHIBs) of the prohibition on navigating in the safety zone around the platform, and although it is indisputable that the Arctic Sunrise was made aware of the pursuit (through a valid auditory signal), while the Russian authorities may have been under the impression that the RHIBs were still in the safety zone, the pursuit was not continuous as required by Article 111(1) UNCLOS. Indeed the boarding of the Arctic Sunrise occurred some 36 hours after the first stop signal and 33 hours after the Russian authorities attempted to board the Arctic Sunrise.

The Tribunal also held that Russia had breached its obligations towards the Netherlands under Articles 290(6) and 296(1) UNCLOS by its failure to comply with paragraphs (1) and (2) of the Order issued by the International Tribunal for the Law of the Sea (ITLOS) of 22 November 2013 (on the basis of Article 290(5) UNCLOS) prescribing provisional measures. ITLOS had ordered Russia, among other things, to release the Arctic Sunrise and its crew upon the posting of a bank guarantee for EUR 3.6 million by the Netherlands.

Open Access This article is distributed under the terms of the Creative Commons Attribution 4.0 International License (http://creativecommons.org/licenses/by/4.0/), which permits unrestricted use, distribution, and reproduction in any medium, provided you give appropriate credit to the original author(s) and the source, provide a link to the Creative Commons license, and indicate if changes were made. 